\title{
ASEAN in the Age of Anti-Globalization: Compartmentalized Regionalism(s) and Three Trajectories
}

\author{
Shofwan Al Banna Choiruzzad 1
}

\begin{abstract}
This essay attempts to examine the prospect of ASEAN integration in the age of antiglobalization by understanding ASEAN as a compartmentalized regionalism. It argues that discussions on the prospect of ASEAN are actually discussions on the trajectories of two separate regional projects: economic regionalism and political security regionalism. It must be noted that we often have difficulties separating the two because their evolution has so far been marked by centripetal movement towards liberal tradition in the two regional projects. However, since we are entering the age of anti-globalization, this is changing. To make an educated guess on the future of ASEAN regionalism(s), I argue that we should focus our attention to three main indicators: (1) Structural: will the international system be cooperative or competitive multipolar system? (2) National elite orientation: will the liberal elites and technocracy in ASEAN countries remain liberal, or will nationalist elites take charge?; and (3) Public sentiment: how big is the positive or negative sentiment towards economic liberalization?
\end{abstract}

Keywords: Regionalism, ASEAN, Compartmentalized Regionalism

\footnotetext{
${ }^{1}$ Lecturer at the Department of International Relations, Faculty of Social and Political Sciences, Universitas Indonesia. Corresponding e-mail: shofwan.albanna@ui.ac.id
} 


\section{Introduction: The Age of Anti-Globalization and ASEAN}

"Fifteen years ago, I wrote a little book, entitled 'Globalization and its Discontents', describing growing opposition in the developing world to globalizing reforms... Now, globalization's opponents in the emerging markets and developing countries have been joined by tens of millions in the advanced countries" (Stiglitz, 2016).

Donald Trump's victory in the United States presidential election is just one symptom of the turbulent age that we are now facing. Today, the world is marked by the emergence of Daesh (ISIS); the rise of right-wing leaders such as Geert Wilders, Le Pen, and Donald Trump; growing tension in the Asia Pacific region; and the stagnation of the European integration project. European regionalism, seen as irreversible for decades, now faces a serious challenge. Talks about European disintegration have begun to appear in the discussions of policymakers and academics (Schmitter \& Lefkofridi, 2016; Legrain, 2016). However, their pessimism has not affected ASEAN leaders. On the organization's 49th anniversary, ASEAN leaders seem continuously optimistic about the future of the ASEAN integration project. The ASEAN Community Vision 2025, adopted by ASEAN leaders in Kuala Lumpur last year, declared that ASEAN leaders are resolved to "consolidate our community, building upon and deepening the integration process."

Is such optimism justified? This essay attempts to look at the prospect of ASEAN integration in the age of anti-globalization by understanding ASEAN as a compartmentalized regionalism: "political project to reorganize a particular regional space along defined economic and political lines, which actually consists of multiple and separated/compartmentalized kinds of arrangements of the regional space(s) but identified as a single project." 2 In simple words, compartmentalized regionalism is "multiple regionalisms in one particular regional space under one name". (Choiruzzad, 2016). It argues that discussions on the prospect of ASEAN are actually discussions on the trajectories of two separate regional projects: economic regionalism and political security regionalism. It must be noted that we often have difficulty separating the two because their evolution has so far been marked by centripetal movement towards

\footnotetext{
2 The definition is built upon Anthony Payne and Andrew Gamble's definition of regionalism. It will be discussed in more details in the next part of this article.
} 
liberal tradition in the two regional projects. However, as we are entering an age of anti-globalization, this is changing. To make an educated guess on the future of ASEAN regionalism(s), I argue that we should focus our attention on three main indicators: (1) Structural: will the international system be cooperative or competitive multipolar system? (2) National elite orientation: will the liberal elites and technocracy in ASEAN countries remain liberal, or will nationalist elites take charge?; and (3) Public sentiment: how big is the positive or negative sentiment towards economic liberalization?

\section{Literature Studies: Regionalism and Globalization ${ }^{3}$}

\section{Conceptual Definition}

Before further discussion, it is important to clarify what this paper means by regionalism and how it is related to other commonly used concepts such as 'regionalization' and 'regional cooperation.' However, it must be acknowledged that these concepts may be understood differently by different scholars. This clarification of the concepts thus serves more as an attempt to explain the position of this paper rather than an intellectual exercise to determine which definition is correct/incorrect or to elaborate the details of the conceptual debates (for conceptual debates, see Hettne, 2005), both of which are beyond the scope of this paper. This paper understands regionalism as the "political project to reorganize a particular regional space along defined economic and political lines". This definition is based on Anthony Payne and Andrew Gamble's definition of regionalism as a "state-led or states-led project designed to reorganize a particular regional space along defined economic and political lines" (Payne \& Gamble, 1996, p. 2) but acknowledges that states are not the only actors involved as drivers in such a process.

Some scholars use the concept of regionalism interchangeably with regionalization (Baldwin, 2007), while some others differentiate the two. Those who distinguish between the two concepts differ in explaining why the two concepts are different. Some scholars distinguish the concept by understanding 'regionalism' as a top down process (mainly driven by political authority, i.e. state) and 'regionalization'

\footnotetext{
3 Parts of sections 2 and 3 are developed from my presentation at AUN-KASEAS International Conference, 26-27 August 2016, titled "Centrality or Centralities: Understanding ASEAN as Compartmentalized Regionalism"
} 
as a more bottom up process (sprang from the need for transnational relations due to economic interdependency). Others see the relationship between 'regionalism' and 'regionalization' as similar to that between 'nationalism' and 'nation building' (Camroux in Dieter, 2007). This paper sees that the two as distinct concepts, with regionalism referring to "a political project to reorganize a particular regional space" and regionalization referring to a "process of forming regions that can emerge both by being planned (i.e.: a political project) or by spontaneous development" (developed from Hettne, 2005, p. 546). With these definitions, both concepts are distinct, but may be used interchangeably in some particular contexts. All regionalisms are regionalization, but not all regionalization can be understood as regionalism (because not all regionalization processes are planned consciously as political projects).

Regional cooperation, on the other hand, is a wider and more general concept that can be understood as referring to any kind of joint efforts by states to solve a specific problem. In Ernst Haas' classical definition, regional cooperation is "a vague term covering any interstate activity with less than universal participation designed to meet commonly experienced need" (Haas, 1970, p. 610). With the above mentioned conceptual understanding, this paper deliberately uses the term 'regionalism', as ASEAN is clearly a political project.

\section{Regionalism and Globalization}

Studies in regionalism began in the 1950s, responding to development in postWorld War II Europe. These early studies on regionalism, first intended to understand and prescribe a strategy for European regional integration but later spread to study other regional projects elsewhere, is often considered 'Old Regionalism'.

Old regionalism approaches are often also considered 'political programs', since they also serve as prescriptions for regional integration. Federalism, an early approach to study regionalism that was very influential among the pioneers of European integration, advocated for the retreat of the nation-state and the formation of a new form of political structure that integrated existing nation-states. The impetus for this argument was the European experience of devastating world wars and the drive to ensure peace in the region. This argument was later criticized by functionalism, often associated with David Mitrany, which argued that function is more important than form (advocated by the federalists). 'Form' (i.e. the international/supranational 
organization) must be established based on 'function', i.e. cooperation and activities around functional needs such as trade, production, welfare, and transportation (Hettne, 2005, p. 546).

Later, functionalists were criticized by neo-functionalists such as Ernst Haas, who disputed functionalists' neglect of politics and argued that those 'functions' are not merely technical but also political (Hettne, 2005, p. 546). Integration, they argued, is not driven by 'functional automaticity', but by process and the existence of purposeful actors. According to neo-functionalists, increasing levels of interdependence would initiate a process that would lead to political integration. One important mechanism related to this argument is 'spillover', which is "the way in which the creation and deepening of integration in one economic sector would create pressures for further economic integration within and beyond that sector and greater authoritative capacity at the European level" (Hettne, 2005, p. 546). ${ }^{4}$ Based on this idea, Bela Balassa developed the influential concept that regional integration should occur in five stages: free trade area will lead to customs union, customs union will lead to common market, common market will lead to economic and monetary union, and finally economic and monetary union will lead to political union (Balassa, 1961; Balassa in Eatwell et al., 1987, pp. 43-47). It must be noted that, despite being published in 1960s and thus potentially labeled 'Old Regionalism', Balassa's concept remains influential in shaping our understanding (and the strategy of policymakers) even today (Dieter, 2000, pp. 7-8).

Despite the internal debates within 'Old Regionalism', its approaches generally consider regionalism to be a linear and relatively mono-dimensional process. Linear means that the process follows a particular trajectory. This does not mean that it necessarily runs in the single direction of progress, since the process can stagnate or even regress. It means that the stages (explicitly mentioned as in Balassa's concept or implicitly assumed) are connected as a series of milestones. Mono-dimensional refers to the tendency to see regionalism as something that happens in one or at least a 'unified' dimension (e.g. security or economy).

\footnotetext{
${ }^{4}$ The use of 'European' here is understandable because Old Regionalism mostly focuses on Europe, which is also empirically the first project of regional integration. 'European level' in this definition has also applied to other regional projects.
} 


\section{Shofwan Al Banna Choiruzzad}

This first wave of regionalism studies was halted with the so-called 'Eurosclerosis' and the stagnation of attempts for regional integration elsewhere in in the 1970s. A new wave of regionalism studies that started in the 1980s was related to the phenomenon of globalization. This new wave of studies is often identified as 'New Regionalism.' However, some scholars have advocated for transcending this division of old and new regionalisms (Hettne, 2005; Hettne \& Soderbaum in Cooper et al., 2008).

'New Regionalism' approaches differ from their 'Old' counterpart by acknowledging the diversity of regionalisms. According to Andrew Hurrel, five distinguishing factors differentiate 'New Regionalism' from 'Old Regionalism': (1) New Regionalism in very diverse, being comprised of a range of models/structures/ processes of region-building rather than a single norm; (2) New Regionalism can involve partnerships between developed and developing countries; (3) New Regionalism varies in the level of institutionalization, in contrast to Old Regionalism's very formal understanding of region building; (4) New Regionalism is multidimensional and blurs the distinction between the economic and the political; and (5) New Regionalism reflects, shapes, and requires the development of a regional sense of identity (Hurrel, 1995). According to Hettne and Soderbaum, 'New Regionalism' considered new aspects related to the phenomenon of globalization. They also argue that New Regionalism focused on concepts of 'regionalism' and 'regionalization' (in contrast to the concepts of 'regional integration' and 'regional cooperation' preferred by earlier studies of regionalism), because those concepts are considered more appropriate for capturing the multidimensional features of contemporary regionalism (Hettne \& Soderbaum in Cooper et al., 2008).

It is also important to note that this distinction of old and new regionalisms does not only apply in a theoretical sense, but also in an empirical sense, as the terms do not only refer to approaches of studying regionalism but also to the regionalism projects themselves. Some regional organizations are considered 'old regionalism' (mostly those established during the Cold War, especially in the 1950s-1970s) and others, especially those effectively established after the 1980s, are considered 'new regionalism.' According to Hettne, 'old regionalism' was a "Cold War phenomenon" and had specific objectives (some security-motivated while others more economically oriented) while 'new regionalism' was a result of a "more comprehensive, 
multidimensional societal process" (Hettne, 2005, p. 549). In this sense, it is interesting to note that ASEAN was established in 1967, with a strong Cold War context, but new elements of the regional project were established in 1990s. This situation has often created confusion for observers, because ASEAN could be considered both 'old' and 'new' regionalism.

If we look at political and security issues, ASEAN meets the description of old regionalism due to its Cold War origins and the continuing importance of the member states. However, this cannot capture the development of many features of ASEAN regionalism after the 1990s, which transcend a single specific dimension. Some would argue that ASEAN is closer to 'new regionalism' because it is considered 'comprehensive and multidimensional' (referring to the existence of three equal pillars of ASEAN Community). However, 'comprehensive and multidimensional' assumes integrality of dimensions, indicated by the existence of unified patterns/rules of arrangement, similar proponents, and a single particular logic on which the regional project operates. This might not be sufficient to explain the frequent disconnection between the economic, security, and socio-cultural 'pillars' of ASEAN and the focal point agencies of each pillar in each country.

\section{Compartmentalized Regionalism}

"Today, power in the world is distributed in a pattern that resembles a complex three-dimensional game" (Nye, 2011).

The limitations of 'Old' and 'New' regionalisms in capturing the abovementioned complexity of ASEAN regionalism demand a more creative approach. To fill this demand, this paper aims to explore the idea of 'compartmentalized regionalism'. This concept argues that ASEAN is a 'political project' composed of at least two different 'political projects' with distinct arrangements, proponents, and logics that are separate but identified politically as a single integrated project.

Joseph Nye's analogy of multidimensional chessboards is relevant in the case of ASEAN regionalism. Furthermore, I believe that actors are not only playing on multiple chessboards simultaneously, but playing different board games with different rules on each layer. The European Union is a multidimensional regionalism project in that it 
creates authority in economics, politics, security, agriculture, environment, as well as some other sectors, in an integrated process based on a coherent arrangement and operating on a particular logic. In the context of the European Union, this logic is "liberal prescription for the conduct of international politics" (Walt, 2015). ASEAN is not only multi-dimensional, because some of the dimensions have arrangements, proponents, and logics that are distinguishable from each other. The dimensions in European regionalism may be chessboards, but the dimensions in ASEAN regionalisms are different board games.

In this paper, I would like to propose that ASEAN regionalism is driven by separated regional projects. ASEAN is a 'political project' composed of at least two different 'political projects'. One is in the political security dimension (in recent developments, manifested in the ASEAN Community in the ASEAN Political Security Community pillar) and the other one is in the economic dimension (manifested in the ASEAN Economic Community pillar). The two have distinguishable arrangements, proponents, and logics that are separate but identified politically as a single integrated project. Thus, I would like to propose the use of the term 'compartmentalized regionalism'.

One symptom of this 'compartmentalized regionalism' is the partial and limited leadership in ASEAN. For example, Emmers observed that Indonesia's leadership has so far been limited to the political and security spheres and left other sectors to others (Emmers, 2014). If we use the framework of compartmentalized regionalism, this is not merely a problem of partial, sectorial, incomplete, or limited leadership in a particular state in ASEAN. It is related to the fact that economic and political security are not merely 'sectors' of ASEAN regionalism, but two distinct regionalisms despite being identified under the single flag of ASEAN. Below, this paper elaborates the distinct arrangement, proponents, and logics that can be used to distinguish between the two regionalism projects under the name of ASEAN regionalism.

\section{Distinct Arrangements}

One visible distinction between the two 'compartments' is that they have different arrangements in organizing the regional space. In the political security compartment, sovereignty and non-interference remain sacred and act as the basic principles for shaping the regional arrangement. "Respect for the independence, 
sovereignty, equality, territorial integrity, and national identity of all ASEAN Member States" is included in the Charter as the first principle of ASEAN. This is apparently not enough, as another principle to guarantee Member States' sovereignty appears in point (k) "Abstention from participation in any policy or activity, including the use of its territory, pursued by any ASEAN Member State or non-ASEAN State or any non-State actor, which threatens the sovereignty, territorial integrity or political and economic stability of ASEAN Member States". The principle of non-interference is mentioned in point (e) "non-interference in the internal affairs of ASEAN Member States" and (f) "respect for the right of every Member State to lead its national existence free from external interference, subversion and coercion".

It is interesting to note that, while the ASEAN Political and Security Community Blueprint emphasizes the importance of the principles contained in the ASEAN Charter ("The APSC Blueprint is guided by the ASEAN Charter and the principles and purposes contained therein"), the ASEAN Economic Community Blueprint directly mentions that "the Leaders agreed to hasten the establishment of the ASEAN Economic Community by 2015 and to transform ASEAN into a region with free movement of goods, services, investment, skilled labour, and freer flow of capital". The AEC Blueprint does not refer specifically to the principles in the ASEAN Charter, but mentions that "ASEAN shall act in accordance to the principles of an open, outward-looking, inclusive, and marketdriven economy consistent with multilateral rules as well as adherence to rules-based systems for effective compliance and implementation of economic commitments". This is, of course, in line with Article 2 Paragraph 2 point (n) of the ASEAN Charter, but with additional words (rather than being solely market driven as in the Charter, additional characteristics are explicitly added: open, outward-looking, and inclusive). Of course, one can argue that this is only a trivial matter of document structure. However, this shows that the two compartments actually have different principles in organizing regional space.

In the 'political security compartment,' sovereignty and non-interference are generally considered as non-negotiable. Thus, ASEAN observers are pessimistic about the possibility of functioning human rights institutions under ASEAN or about the prospect of ASEAN's democratization agenda (Kvanvig, 2008; Dosch, 2008, pp. 527545). However, in the economic compartment, it seems that sovereignty can, and even must, be compromised. Rather than stressing the importance of sovereignty, the AEC 
Blueprint emphasizes that ASEAN Member Countries shall adhere to "rules-based systems for effective compliance and implementation of economic commitments". To comply and implement economic commitment, one must compromise at least part of its sovereignty.

As already mentioned, one symptom of 'compartmentalized regionalism' is the partial and limited leadership in ASEAN. This is also an indicator that the 'compartments' are driven by different champions with different motivations. The political security regionalism/compartment was formed and initiated by ASEAN Member States during the Cold War. It is in this context that the principle of noninterference was outlined as the ASEAN principle, as mentioned in the Bangkok Declaration. From the 1960 s to the 1980s, ASEAN successfully managed to prevent large conflict and provide regional stability. This is an important achievement if we compare ASEAN with other regions that were devastated by conflicts spurred by the interference of competing blocs. Thus, states played a very important role in the shaping of regional cooperation in security. This has continued after the end of the Cold War and the rise of China that set new geopolitical complexity in the region. However, states continue to act similarly, with their own national interests acting as their guiding lights. In this compartment, countries with large size and huge strategic interests such as Indonesia act as sectorial leaders. It must be noted that, despite the existence of the non-interference principle, external powers such as US, Japan, and China are also competing for influence in shaping the regional security architecture.

The economic regionalism/compartment was initiated by different proponents. Some scholars argue that ASEAN regionalism (in the context of this paper, the 'economic regionalism' part) has been largely driven by the private sector, especially by the activities of the Japanese Multinational Corporations (MNCs) and overseas Chinese businesses, while states have only played secondary and reactive roles (Stubbs, 1995, pp. 785-797). This has changed since the Asian Crisis of 1997/1998, which spurred the emergence of a more active role of states in shaping the regional project (Bowles, 2002, pp. 244-270). In this compartment, Singapore plays a significant role, and external economic powers such as Japan and China act as important proponents. For example, Japan helped establish and sustain ERIA (Economic Research Institute for ASEAN and East Asia), a think tank that is very influential in providing recommendations for ASEAN economic integration. 
Domestically, the separation between the two compartments is also visible. Different focal points (especially Ministry of Foreign Affairs and Ministry of Defense vs. Ministry of Trade) often have different ideas of ASEAN and how it should interact with external powers. However, these differences are not becoming a problem because they have their own 'compartments' that are institutionalized through ASEAN mechanisms.

\section{Distinct Logics}

Lastly, the two compartments are different because they operate based on different logics. The difference in the regional arrangement and its proponents are strongly correlated to the difference in the ideological perspective that serves as the basis of the regional project. The political security compartment operates on a Westphalian logic that stresses the importance of the state and territoriality, while the economic compartment relies on the insights of the technocrats that believe in economic liberalism. The former is concerned with relative gain, while the latter is concerned mostly with absolute gain.

To sum up, the differences that separate the two compartments can be outlined as follows:

Table 1. The Different Features of Political Security and Economic Compartments of ASEAN Regionalism

\begin{tabular}{|c|c|c|}
\hline & $\begin{array}{l}\text { Political Security } \\
\text { 'Compartment' }\end{array}$ & $\begin{array}{l}\text { Economic } \\
\text { 'Compartment' }\end{array}$ \\
\hline Arrangements & $\begin{array}{l}\text { Sovereignty is the } \\
\text { basis and thus cannot } \\
\text { be compromised. }\end{array}$ & $\begin{array}{l}\text { Some parts of national } \\
\text { sovereignty must be } \\
\text { compromised. }\end{array}$ \\
\hline Proponents & $\begin{array}{l}\text { ASEAN Member } \\
\text { States, Defense } \\
\text { Ministries, competing } \\
\text { regional powers }\end{array}$ & $\begin{array}{l}\text { Business (MNCs), } \\
\text { Economic Ministries, } \\
\text { regional economic } \\
\text { powers }\end{array}$ \\
\hline Logics & $\begin{array}{l}\text { Westphalian, state- } \\
\text { centric, relative gain }\end{array}$ & $\begin{array}{l}\text { Economic liberalism, } \\
\text { open regionalism, } \\
\text { absolute gain }\end{array}$ \\
\hline
\end{tabular}

\section{Possible Scenarios}

Based on the understanding of ASEAN as compartmentalized regionalism, discussion of the prospect of ASEAN is actually on the trajectories of two separate regional projects: economic regionalism and political security regionalism. 
Nevertheless, it must be noted that we often have difficulty separating the two because their evolution has so far been marked by centripetal movement towards liberalization in the two regional projects.

In the economic compartment, the move toward a more liberal tendency is evident in itself, since economic liberalism is the driving idea of the economic regionalism project. As such, every progress in regional economic integration is in itself a move toward liberalism. In the political compartment, despite the stubborn persistence of Westphalian notions of sovereignty and non-interference, ASEAN is constantly moving towards a more liberal arrangement (Kurniawan, 2015, pp. 4-6).

In the beginning, ASEAN member states preserved security in the region by declaring their commitment towards principles of national sovereignty and noninterference to end regional inter-state violent political conflicts. This means that ASEAN countries were following realist tradition, as they recognized the anarchic nature of the international system. Later, this situation gradually changed with the introduction of regional codes of conduct such as Zone of Peace, Freedom, and Neutrality (ZOFPAN); the Treaty of Amity and Cooperation (TAC); and the Southeast Asia Nuclear-Weapon-Free Zone (SANWFZ). The move toward a more liberal arrangement became faster with the end of the Cold War and was marked by the establishment of the ASEAN Regional Forum (ARF) in 1994, which was intended to engage major powers in East Asia and beyond in a cooperative security mechanism. The establishment of ARF, with its assumption that it should be able to evolve as a "community of law security system" in the long run (Navari in Williams, 2008, p. 42; Kurniawan, 2015), indicates a further step towards liberal ideas of maintaining security. The latest milestone in the shift towards liberalism is the establishment of the ASEAN Political Security community (APSC) as one of the pillars of the ASEAN Community. Under the APSC, ASEAN leaders envision a secure Southeast Asia with three key characteristics: (1) a rules-based community of shared values and norms; (2) a cohesive, peaceful, stable, and resilient region with shared responsibility for comprehensive security; and (3) a dynamic and outward-looking region in an increasingly integrated and interdependent world (APSC Blueprint Report 2009).

What explains this constant shift towards a more liberal orientation and the creation of a pathway for unifying the two regional projects? The first is structural, i.e. the global and regional distribution of power. The end of the Cold War brought a shift 
from a bipolar to unipolar international system with liberalism as the triumphant ideology. The second factor is elite orientation. After their independence in the mid$20^{\text {th }}$ century, most countries in South East Asia in the 1980s began to have their own groups of technocrats and elites with a liberal orientation. This is related to the growth of post-independence generations; education orientation, mostly toward Western universities; and the elimination of leftist groups, seen by many South East Asian regimes as domestic threats, at the height of the Cold War. The third is the public sentiment that generally expect the world to become more integrated after the lengthy tensions of the Cold War.

However, with the upcoming age of anti-globalization, changes are occurring to these three factors. Based on this assessment, what are the possible trajectories of ASEAN regionalism, i.e. the two regional projects? Will the centripetal move towards a liberal tradition (and thus integrate the compartments into a more European Unionlike multidimensional arrangement) continue (Scenario 1)? Or will reversals happen? If reversals occur, will there be a return to two separated regional arrangements (realist regional political and security order and continuing liberalization of regional economic arrangement, Scenario 2)? Or, will the conflation of the economic and political compartments, driven by competitive Great Power politics, leads to the collapse of ASEAN (Scenario 3)?

To make an educated guess on the future of ASEAN regionalism(s), I argue that we should focus our attention to three main indicators: (1) Structural: will the international system be cooperative or competitive multipolar system? (2) National elite orientation: Will the liberal elites and technocracy in ASEAN countries remain liberal, or will nationalist elites take charge?; and (3) Public sentiment: How big is the positive or negative sentiment towards economic liberalization? The three possible scenarios are outlined in the table below.

Table 2. Scenarios for the Trajectories of ASEAN Regionalism(s)

\begin{tabular}{|c|c|c|c|}
\hline & $\begin{array}{l}\text { Scenario 1: } \\
\text { Multidimensional } \\
\text { Liberal Regionalism }\end{array}$ & $\begin{array}{l}\text { Scenario 2: } \\
\text { Continued } \\
\text { Separation }\end{array}$ & $\begin{array}{l}\text { Scenario 3: } \\
\text { Conflation and } \\
\text { Collapse }\end{array}$ \\
\hline Structural & $\begin{array}{l}\text { Multipolar with } \\
\text { cooperative Great } \\
\text { Power dynamics }\end{array}$ & $\begin{array}{l}\text { Multipolar with } \\
\text { competitive Great } \\
\text { Power dynamics }\end{array}$ & $\begin{array}{l}\text { Multipolar with } \\
\text { competitive Great } \\
\text { Power dynamics }\end{array}$ \\
\hline
\end{tabular}




\begin{tabular}{llll}
\hline $\begin{array}{l}\text { National Elite } \\
\text { Orientation }\end{array}$ & $\begin{array}{l}\text { Persisting liberal } \\
\text { elite and technocracy }\end{array}$ & $\begin{array}{l}\text { Persisting liberal } \\
\text { elite and } \\
\text { technocracy }\end{array}$ & $\begin{array}{l}\text { Rise of nationalist } \\
\text { elites }\end{array}$ \\
\hline Public Sentiment & $\begin{array}{l}\text { Moderate to high } \\
\text { support towards } \\
\text { economic } \\
\text { liberalization }\end{array}$ & $\begin{array}{l}\text { Moderate to high } \\
\text { support toward } \\
\text { economic } \\
\text { liberalization }\end{array}$ & $\begin{array}{l}\text { Low to moderate } \\
\text { support toward } \\
\text { economic } \\
\text { liberalization }\end{array}$ \\
& & $\begin{array}{l}\text { No huge organized } \\
\text { resistance against } \\
\text { economic } \\
\text { liberalization }\end{array}$ & $\begin{array}{l}\text { Rise of economic } \\
\text { nationalism }\end{array}$ \\
\hline
\end{tabular}

For now, it is too early to judge the fate of ASEAN. Things are changing, certainly. On the structural dimension, most observers agree that the region, and even the world, is shifting towards a multipolar structure. Nevertheless, it is difficult to define the dynamics of great power rivalry in the region between China, Japan, and the United States as cooperative or competitive in clear-cut manner.

Competition does characterize the relationship between China and Japan, as seen in the competition of the Asia Plus Three (APT) that limits is membership to ASEAN+3 countries and the East Asia Summit (EAS) which includes Australia, New Zealand, India, the United States, and Russia. Competition is also evident in the establishment of China-led Asia Infrastructure Investment Bank vis a vis existing institutions led by Japan (Asia Development Bank) and the United States (the World Bank) and the introduction of the One Belt One Road (OBOR) initiative vis a vis Japan's Partnership for Quality Infrastructure introduced by Prime Minister Abe in May 2015. However, Japan and China do cooperate in many ASEAN-based frameworks, including in the development of the Greater Mekong Sub-region.

On the aspects of national elite orientation and public sentiment, the rise of antiglobalization sentiment, as illustrated by the rise of Trump and his policies, will pose challenges against the generally liberal elite and technocracy of the current ASEAN governments. Nationalist sentiments do appear more expressively in ASEAN member countries' politics, such as during Indonesia's presidential campaign (despite the fact that, after the election, economic policies have generally remained in the liberal precepts) and Malaysian political bickering. So far, the economic technocracy of ASEAN countries remains generally supportive of free trade. However, changes often happen abruptly, as in the case of Trump or pre-World War II turns into protectionism. 
For now, the most probable scenario is the status quo: that the ASEAN economic regionalism and ASEAN's political security regionalism will remain separated, despite being under the single banner of the ASEAN Community. In the economic realm, economic integration will continue, albeit slowly. In the political security realm, the gradual shift toward liberal precepts will be reversed. Nevertheless, predictions are predictions, and no single academic work can guarantee the accuracy of its predictions. We will have to wait for the future to unravel itself.

\section{References}

ASEAN Secretariat. (2009). ASEAN Economic Community Blueprint. Jakarta: ASEAN Secretariat.

. (2009). ASEAN Political Security Community Blueprint. Jakarta: ASEAN Secretariat.

(2009). ASEAN Socio-Cultural Community Blueprint. Jakarta: ASEAN Secretariat.

Balassa, B. (1961). The Theory of Economic Integration. Illinois: Richard Irwin.

Baldwin, R. (2007). Managing the Noodle Bowl: The Fragility of East Asian Regionalism. CEPR Discussion Paper Series, 5561, 2007.

Bowles, P. (2002). Asia's Post-Crisis Regionalism: Bringing the State Back In, Keeping the United States Out. Review of International Political Economy, 9(2), 244-270.

Choiruzzad, S. A. (2016, August 26-27). Centrality or Centralities? Understanding ASEAN as Compartmentalized Regionalism. Paper presented at AUN-KASEAS International Conference, Seoul.

Cooper, A. F., Hughes, C. W., \& De Lombaerde, P. (Eds.). (2008). Regionalisation and Global Governance: The Taming of Globalisation? New York: Routledge.

Dieter, H. (2000). Monetary Regionalism: Regional Integration without Financial Crises. CSGR Working Paper, 52/00, May 2000.

Dieter, H. (Ed.). (2007).The Evolution of Regionalism in Asia. New York: Routledge.

Dosch, J. (2008). ASEAN's Reluctant Liberal Turn and the Thorny Road to Democracy Promotion. The Pacific Review, 21(4), 527-545.

Eatwell, J., Milgate, M., \& Newman, P. (Eds.). (1987). The New Palgrave: A Dictionary of Economics. Vol. 2 (E to J). London and Basingstoke: Macmillan. 
Emmers, R. (2014). Indonesia's Role in ASEAN: A Case of Incomplete and Sectorial Leadership. The Pacific Review, 27(4).

Haas, E. B. (1970). The Study of Regional Integration: Reflections on the Joy and Anguish of Pretheorizing. International Organization, 24(4).

Hettne, B. (2005). Beyond the 'New' Regionalism. New Political Economy, 10(4), 543570.

Hurrel, A. (1995). Explaining the Resurgence of Regionalism in World Politics, Review of International Studies, 21, 331-358.

Kurniawan, Y. (2015). Liberalizing ASEAN Security Architecture. ASEAN Insights. March 2015.

Kvanvig, G. (2008). ASEAN, Sovereignty and Human Rights. Retrieved from http://www.jus.uio.no/smr/english/about/programmes/vietnam/docs/aseansovereignty-and-human-rights---gisle-kvanvig.pdf.

Legrain, P. (2016). Three Paths to European Disintegration. Retrieved from https://www.project-syndicate.org/commentary/brexit-european-uniondisintegration-by-philippe-legrain-2016-08?barrier=accessreg

Nye Jr., J. S. (2011). The Future of Power. New York: Public Affairs.

Payne, A., \& Gamble, A. (Eds.). (1996). Regionalism and World Order. New York: McMillan.

Schmitter, P. C., \& Lefkofridi Z. (2016). Neofunctionalism as a Theory of Disintegration. Chinese Political Science Review, 1(1).

Stiglitz, J. E. (2016). Globalization and Its New Discontents. Retrieved from https://www.project-syndicate.org/commentary/globalization-newdiscontents-by-joseph-e--stiglitz-2016-08?barrier=true

Stubbs, R. (1995). Asia-Pacific Regionalization and the Global Economy: A Third Form of Capitalism. Asian Survey, 35(9), 785-797.

Walt, S. M. (2015). Back to the Future: World Politics Edition. Foreign Policy, July. Retrieved from http://foreignpolicy.com/2015/07/08/back-to-the-futureworld-politics-edition-russia-isis-europe-china/

Williams, P. D. (2008). Security Studies: An Introduction. London and New York: Routledge. 